\title{
PENGARUH RETURN ON EQUITY DUPONT SYSTEM TERHADAP RETURN SAHAM PADA PERUSAHAAN BATU BARA YANG TERDAFTAR DI INDONESIA STOCK EXCHANGE (IDX)
}

\author{
Adriana Rahmawati, Evi Martaseli
}

Universitas Muhammadiyah Sukabumi (UMMI) Jawa Barat, Indonesia

Email: rahma.adriana@gmail.com, evimartaseli@yahoo.com

\section{Abstrak}

Pasar merupakan tempat berkumpulnya sejumlah pembeli dan sejumlah penjual di mana terjadi transaksi jual-beli barang-barang yang ada di sana. Menurut cara transaksinya pasar dibedakan menjadi pasar tradisional dan pasar modern. Penelitian ini bertujuan untuk melihat apakah terdapat secara parsial antara return on equity dupont terhadap return saham. Penelitian ini merupakan penelitian yang bersifat kuantitatif dengan uji statistik. Populasi yang digunakan pada penelitian ini adalah seluruh perusahaan batu bara yang terdaftar di Indonesia stock exchange periode 2014-2019 sebanyak 23 perusahaan. Teknik yang digunakan dalam penelitian ini adalah menggunakan purposive sampling, dengan kriteria yang digunakan sebagai berikut: (1) Perusahaan batu bara yang terdaftar di Indonesia Stock Exchange (IDX) tahun 2014-2019 (2) Perusahaan batu bara yang menerbitkan laporan keuangan lengkap selama tahun 2014-2019 (3) Perusahaan batu bara yang tidak melakukan stock split. Teknik analisis data yang digunakan pada penelitian ini adalah analisis linier berganda yang digunakan untuk mengetahui apakah terdapat pengaruh antara variabel independem terhadap variabel dependen. Hasil uji menunjukam hipotesis menunjukan net profit margin dan total asset turnover tidak berpengaruh secara parsial terhadap return saham, sedangkan equity multiplier dan return on equitydupont berpengaruh secara signifikan terhadap return saham. Sedangkan hasil uji f menunjukan net profit margin, total asset turnover, equity multiplier dan return on equity-dupont berpengaruh secara simultan terhadap return saham.

Kata Kunci: margin laba bersih; total perputaran aset; pengganda ekuitas; pengembalian sistem ekuitas-dupont; return saham

\section{Abstract}

The market is a gathering place for a number of buyers and a number of sellers where there is a transaction to buy and sell goods that are there. According to the way the market is transactioned the market is distinguished into a traditional market and a modern market. The study aims to see if there is a partial return on equity to the return on equity of the stock. This research is a quantitative study with statistical tests. The population used in this study is all coal companies listed on the Indonesia stock exchange for the period 2014-2019 as many as 23 companies. The technique used in this study is to use purposive sampling, with the criteria used as follows: (1) Coal companies registered on the Indonesia

$\begin{array}{ll}\text { How to cite: } & \text { Rahmawati, A., \& Martaseli, E. (2021) Pengaruh Return on Equity Dupont System Terhadap } \\ & \text { Return Saham pada Perusahaan Batu Bara yang Terdaftar Di Indonesia Stock Exchange (IDX), } \\ & \text { Syntax Idea, 3(8), https://doi.org/10.36418/syntax-idea.v6i8.1404 } \\ \text { E-ISSN: } & 2684-883 X\end{array}$


Stock Exchange (IDX) in 2014-2019 (2) Coal companies that issued complete financial statements during 2014-2019 (3) Coal companies that did not do stock splits. The data analysis technique used in this study is a multiple linear analysis used to find out if there is an influence between independem variables on dependent variables. The test results point to the hypothesis that net profit margin and total asset turnover have no partial effect on stock returns, while equity multiplier and return on equity-dupont significantly affect stock returns. While the results of the $f$ test showed net profit margin, total asset turnover, equity multiplier and return on equity-dupont affect simultaneously on stock returns.

Keywords: net profit margin; total asset turnover; equity multiplier; return on equity-dupont system; return saham

\section{Pendahuluan}

Pasar modal mempunyai peran penting bagi perekonomian suatu negara sebab melaksanakan dua fungsi, sebagai sarana pendanaan usaha atau sarana bagi perusahaan untuk menerima dana dari masarakat (investor). Fungsi lain dari pasar modal yakni sebagai sarana bagi masyarakat untuk beinvestasi dengan tujuan mendapatkan profit melalui intrumen keuangan beupa saham, obligasi, reksadana, waran, dan lain-lain sesuai dengan keistimewaan dan resiko dari masing-masing instrumen keuangan (Irham, 2012).

Tujuan dari investasi adalah untuk mendapatkan return atau dividen yang dibagikan perusahaan. Return adalah pengembalian saham atau profit yang diberikan terhadap pemberi modal (investor) yang telah menjalankan investasi pada suatu perusahaan, namun setiap investasi dalam saham mengandung resiko (Suteja, Jaja. Gunardi, 2016).

Salah satu cara investor dalam memprediksi resiko serta return yang akan diterima, yaitu dengan melakukan analisis fundamental, analisis ini digunakan untuk melihat kinerja perusahaan. Pengukuran kinerja perusahaan, merupakan dasar untuk mengevaluasi efesiensi dan efektivitas perusahaan dalam menghasilkan laba. Untuk menganalisis laporan keuangan tersebut, peneliti menggunakan Metode Du Pont Sysem.

Metode DuPont system merupakan analisa bersifat menyeluruh, karena bukan hanya menilai tingkat keuntungan atas laba bersih yang dihasilkan perusahaan, namun mencangkup tingkat efisiensi perusahaan dalam penggunaan aktivanya dapat mengukur tingkat keuntungan atas penjualan produk yang dihasilkan perusahaan. Metode DuPont System menguaraikan kembali rasio Return On Equity menjadi rasio yang lebih spesifik yang dhitung menggunakan tiga indicator, diantaranya;

Net profit margin merupakan rasio yang menggambarkan kinerja perusahaan dalam menghasilkan laba bersih melalui penjualan bersihnya (Hery, 2016)

Total asset turnover merupakan rasio yang menggambarkan efisiensi perputaran aktiva yang dilihat dari volume penjualan (Izuddin, 2018). 
Multiplier equity merupakan rasio untuk mengukur kemampuan manajemen dalam mengelola ekuitasnya jika dibandingkan dengan aktiva yang terdapat pada perusahaan (Damayanti, Yudhawati, \& Prasetyowati, 2017).

Dengan menggunakan DuPont System, investor dapat menilai kinerja keuangan dengan melihat efektivitas penggunaan aktiva dalam memperoleh laba, sehingga pada akhirnya investor dapat menentukan pilihan perusahaan yang tepat ketika akan menanamkan modalnya.

Penelitian mengenai return saham telah banyak dilakukan, mengingat meningkatnya jumlah investor setiap tahunnya. Analisis fundamental merupakan faktor penting agar investor mendapatkan return saham yang sesuai dengan harapan investor. Salah satunya oleh (Sunardi, 2019) pada penelitian yang dilakukan oleh Nardi Sunardi menunjukan hasil Hasil penelitian ini menunjukan bahwa variabel Total Asset Turnover (TATO) mempunyai pengaruh positif dan signifikan terhadap Harga Saham. Net Profit Margin (NPM) berpengaruh positif dan tidak signifikan terhadap Harga Saham. Multiplier Equity Ratio (MER) berpengaruh positif dan signifikan terhadap Harga Saham. Return Equity Ratio-Du Pond (ROE-DP) berpengaruh negatif terhadap Harga Saham. Total Asset Turnover (TATO) berpengaruh negatif terhadap Return Saham. Net Pofit Margin berpengaruh positif terhadap Return Saham. Multiplier Equity Ratio (EMR) berpengaruh positif terhadap Return Saham. Return On equity Du Pont (ROE-DU) berpengaruh terhadap Return Saham.

\section{Metode Penelitian}

Penelitian ini merupakan jenis penelitian kuantitatif dengan menggunakan uji statistik. Penelitian ini bertujuan untuk menguji pengaruh variabel independen terhadap variabel dependen. Variabel dependen pada penelitian ini diantaranya; net profit margin, total asset turnover, equity multiplier dan return on equity dupont, dan variabel dependen pada penelitian ini adalah return saham. Data kuantitatif pada penelitian ini berupa laporan keuangan perusahaan batubara periode 2014-2019 yang terdaftar di Indonesia Stock Exchange (IDX). Sumber data yang digunakan pada penelitian ini diperoleh dengan mendownload laporan keuangan dari situs IDX.

Populasi pada penelitian ini adalah perusahaan batu bara yang terdaftar di Indonesia Stock Exchange (IDX) periode 2014-2019 sebanyak 23 perusahaan. Teknik pengambilan sampel yang digunakan merupakan teknik purposive sampling. Teknik yang digunakan pada penelitian ini dilakukan dengan menentukan kriteria sebagai berikut:

1. Perusahaan batu bara yang terdaftar di Indonesia Stock Exchange (IDX) tahun 2014-2019;

2. Perusahaan batu bara yang menerbitkan laporan keuangan lengkap selama tahun 2014-2019; dan

3. Perusahaan batu bara yang tidak melakukan stock split. 
Kriteria sampel yang digunakan dalam penelitian sebagai berikut:

Tabel 1

Kriteria Sampel Penelitian

\begin{tabular}{llc}
\hline No & \multicolumn{1}{c}{ Deskripsi/Kriteria } & $\begin{array}{c}\text { Jumlah } \\
\text { Perusahaan }\end{array}$ \\
\hline 1 & $\begin{array}{l}\text { Perusahaan batu bara yang terdaftar di Indonesia Stock } \\
\text { Exchange (IDX) tahun 2014-2019. }\end{array}$ & 23 \\
\hline 2 & $\begin{array}{l}\text { Perusahaan batu bara yang menerbitkan laporan } \\
\text { keuangan lengkap selama tahun 2014-2019. }\end{array}$ & $(2)$ \\
\hline 3 & Perusahaan batu bara yang tidak melakukan stock split. & $(6)$ \\
\hline Jumlah perusahaan yang dijadikan sampel & 15 \\
\hline
\end{tabular}

Sumber: www.idx.co.id yang diolah

Teknik analisis data yang digunakan pada penelitian ini adalah analisis regresi linier berganda, yang digunakan untuk mengetahui pengaruh signifikan antara variabel independen terhadap variabel dependen yang ada pada penelitian. Pada penelitian ini software yang digunakan adalah SPSS versi 23.

\section{Hasil dan Pembahasan}

\section{A. Hasil Penelitian}

\section{a. Uji Asumsi Klasik}

Tujuan dari uji asumsi klasik merupakan untuk memberikan jawaban bahwa persamaan regresi yang didapatkan memiliki ketepatan dalam estimasi, tidak bias dan konsisten. Uji asumsi klasik pada penelitian ini adalah uji normalitas, multikolinearitas, heteroskedastisitas dan autokorelasi.

\section{b.Uji Normalitas}

Uji normalitas merupakan pengujian asumsi untuk mengetahui data hasil penelitian berdistribusi normal atau tidak. Uji normalitas terpenuhi apabila sampel yang digunakan lebih dari 30, untuk mengetahui normalitas distribusi data dapat dilakukan menggunakan analisis statistik, yaitu Kolmogrov-Smirnov (Ghozali, 2018). Dengan pengambilan keputusan dengan menggunakan Uji Normalitas Kolmogrov-Smirnov sebagai berikut: (1) Jika sig $\geq 0,05$ berarti data sampel yang diambil terdistribusi normal. (2) Jika sig $\leq 0,05$ berarti data sampel yang diambil terdistribusi tidak normal. 
Tabel 2

Hasil Uji Normalitas

One-Sample Kolmogorov-Smirnov Test

\begin{tabular}{|c|c|c|}
\hline & & $\begin{array}{c}\text { Unstandardized } \\
\text { Residual }\end{array}$ \\
\hline $\mathrm{N}$ & & 90 \\
\hline \multirow[t]{2}{*}{ Normal Parameters ${ }^{\mathrm{a}, \mathrm{b}}$} & Mean &, 0000000 \\
\hline & $\begin{array}{l}\text { Std. } \\
\text { Deviation }\end{array}$ & 94,66441477 \\
\hline Most Extreme & Absolute & 237 \\
\hline \multirow[t]{2}{*}{ Differences } & Positive & ,237 \\
\hline & Negative &,- 148 \\
\hline Test Statistic & & ,237 \\
\hline Asymp. Sig. (2-tailed) & &, $000^{\mathrm{c}}$ \\
\hline \multicolumn{3}{|c|}{ a. Test distribution is Normal. } \\
\hline \multicolumn{2}{|c|}{ b. Calculated from data. } & \\
\hline
\end{tabular}

Berdasarkan hasil uji normalitas diatas diketahui nilai Asymp Sig sebesar $0,000<0,05$ ini dapat disimpulkan bahwa data berdistribusi tidak normal. Oleh karena itu peneliti melakukan outlier data dengan nmenghilangkan data dengan nilai ekstrim. Setelah dilakukan outlier data terdapat 54 data yang memiliki nilai ekstrim dan tersisa 36 data.

\section{Tabel 3}

Hasil Uji Normalitas Data Outlier

\begin{tabular}{llr}
\hline \multicolumn{3}{c}{ One-Sample Kolmogorov-Smirnov Test } \\
\hline & \multicolumn{1}{c}{$\begin{array}{c}\text { Unstandardized } \\
\text { Residual }\end{array}$} \\
\hline $\mathrm{N}$ & \multicolumn{1}{c}{36} \\
\hline Normal Parameters $^{\text {a,b }}$ & Mean &, 0000000 \\
\cline { 2 - 3 } & $\begin{array}{l}\text { Std. } \\
\text { Deviation }\end{array}$ \\
\hline Most Extreme & Absolute &, 139 \\
\cline { 2 - 3 } Differences & Positive &, 139 \\
\cline { 2 - 3 } & Negative &, 112 \\
\hline Test Statistic & &, 139 \\
\hline Asymp. Sig. (2-tailed) & & \\
\hline a. Test distribution is Normal. & \\
\hline b. Calculated from data. & \\
\hline c. Lilliefors Significance Correction. &
\end{tabular}

Berdasarkan tabel 3 dapat diketahui nilai Asymp. Sig sebesar 0,76>0,05 maka dapat disimpulkan data berdistribusi normal. Dengan demikian asumsi residual berdistribusi normal terpenuhi. 


\section{c. Uji Multikolinearitas}

Multikolinearitas digunakan untuk mengukur pengaruh variabel independen terhadap variabel independen lainnya dengan menggunakan regresi tersebut. Model regresi dikatakan baik jika tidak terjadi korelasi antara variabel independen. Pengujian Multikolinearitas menggunakan Variance Inflationfactor (VIF) dengan kriteria model regresi bebas, multikolinearitas mempunyai angka tolerance mendekati 1 . Batas VIF adalah 10, jika nilai VIF dibawah 10, maka tidak terjadi gejala multikolinearitas (Ghozali, 2018).

\section{Tabel 4}

Hasil Uji Multikolinearitas Coefficients $^{\mathrm{a}}$

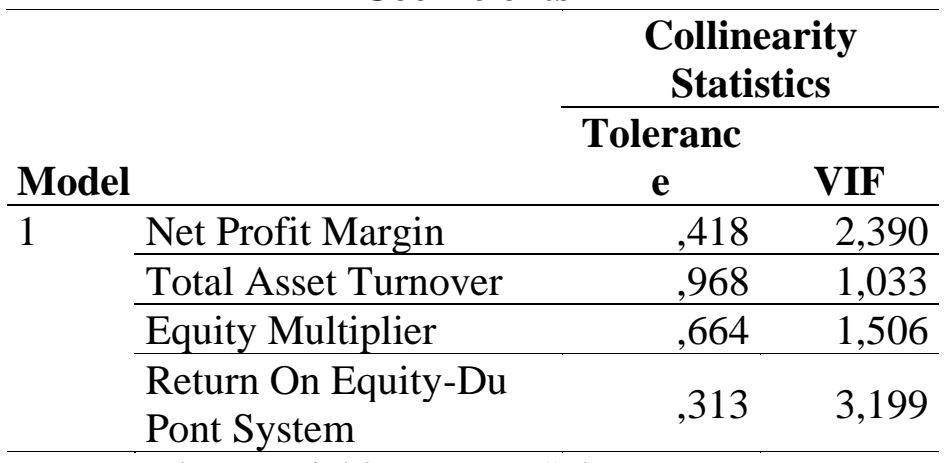

a. Dependent Variable: Return Saham

Berdasarkan hasil uji pada tabel 4 dapat dilihat nilai tolerance Net Profit Margin 0,418 $>0,1$ dan nilai VIF sebesar 2,390 < 10, nilai tolerance Total Asset Turnover $0,968>0,1$ dan nilai VIF sebesar $1,033<10$, nilai tolerance Equity Muliplier 0,664 > 0,1 dan nilai VIF sebesar 1,506 dan nilai tolerance Return on Equity-DuPont System 0,313 > 0,1 dan nilai VIF sebesar 3,199.

Berdasarkan hasil uji diatas dapat disimpulakn bahwa, variabel independen memiliki nilai tolerance lebih dari 0,1 dan nilai VIF kurang dari 10 maka, dapat disimpulkan data tidak terjadi gejala multikolinearitas.

\section{d.Uji Heteroskedastisitas}

Uji heteroskedastisitas bertujuan untuk menguji apakah model regresi terjadi ketidak samaan varians dari residual atas satu pengamatan ke pengamatan yang lain. Untuk mengetahui adanya heteroskedastisitas dalam penelitian ini menggunakan grafik scatterplot. Apabila titik-titik menyebar secara acak dan tidak berkumpul pada suatu titik maka disimpulkan bahwa data tidak terjadi masalah heteroskedastisitas (Ghozali, 2018). 


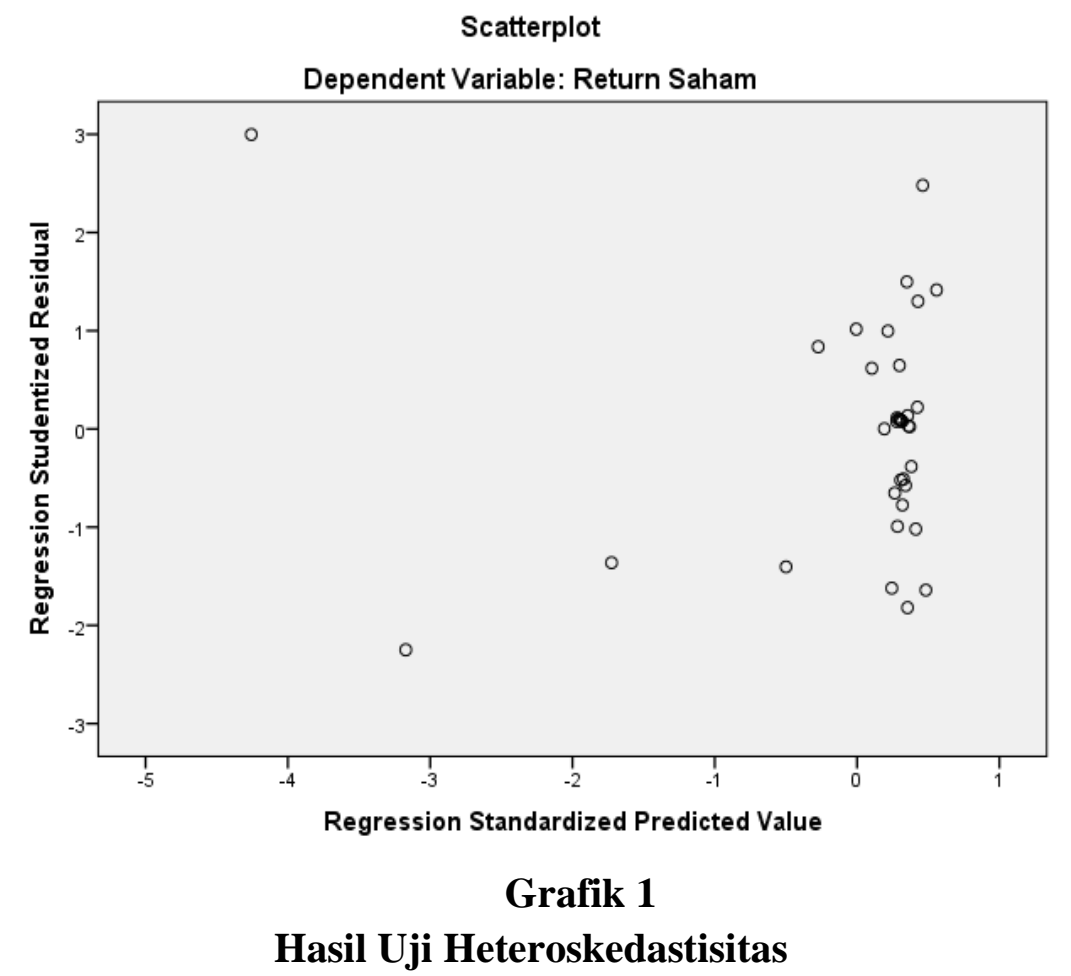

Berdasarkan grafik 1 dapat dilihat titik-titik menyebar secara acak tidak membentuk pola yang jelas dan menyebar dibawah dan diatas atau disekitar angka 0. Dapat disimpulkan bahwa model regresi terjadi heteroskeditas dan tidak terjadi gejala heteroskeditas. Sehingga persamaan regresi yang diuji telah memenuhi asumsi heteroskeditas.

\section{e. Uji Autokorelasi}

Auto korelasi merupakan keadaan dimana pada model regresi terdapat korelasi residual pada periode $\mathrm{t}$ dengan residual sebelumnya ( $\mathrm{t}-1)$. Model regresi yang baik yaitu tidak terdapat masalah autokorelasi. Autokorelasi bisa terjadi karena observasi yang berurutan sepanjang waktu berkaitan dengan satu dan lainnya (Ghozali, 2018). Untuk mendeteksi terdapat autokorelasi atau tidak ada autokorelasi pada penelitian ini dilakukan uji durbin Watson (uji DW) dengan pengambilan keputusan sebagai berikut:

Du < dw < 4-du, maka "H" _"0" diterima, artinya tidak terjadi autokorelasi.

Dw < dl atau dw > 4-dl, maka "H" _"0" ditolak, artinya terjadi autokorelasi.

$\mathrm{Dl}<\mathrm{dw}<\mathrm{du}$ atau $4 \mathrm{du}<\mathrm{dw}<4 \mathrm{dl}$, artinya tidak ada kepastian atau kesimpulan yang pasti. 
Tabel 6

\begin{tabular}{lcrccc}
\hline \multicolumn{5}{c}{ Model Summary $^{\mathbf{b}}$} \\
\hline Model & $\mathbf{R}$ & R Square & $\begin{array}{c}\text { Adjusted R } \\
\text { Square }\end{array}$ & $\begin{array}{c}\text { Std. Error of } \\
\text { the Estimate }\end{array}$ & $\begin{array}{c}\text { Durbin- } \\
\text { Watson }\end{array}$ \\
\hline 1 & $.733^{\mathrm{a}}$ & .537 & .477 & 7.41547 & 1.892 \\
\hline a. Predictors: (Constant), Return On Asset-Du Pont System, Total Asset \\
Turnover, Equity Multiplier, Net Profit Margin \\
\hline b. Dependent Variable: Return Saham \\
\hline
\end{tabular}

Berdasarkan hasil uji autokorelasi pada tabel 6, nilai durbit Watson sebesar 1,892. Dengan nilai du $1,7245<\mathrm{dw} 1,892<4-\mathrm{du}$ sebesar 2,2755 yang artinya $\mathrm{H}_{0}$ diterima dan tidak terjadi autokorelasi.

\section{f. Uji Hipotesis}

Pengujian hipotesisis berkaitan dengan pengaruh antara variabel independen terhadap variabel dependen, adapun uji hipotesisi yang digunakan dalam penelitian ini adalah sebagai berikut: analisis regresi linier berganda, uji $\mathrm{t}$, uji f dan koefesien determinasi.

g. Analisis Regresi Linear Berganda

tabel 7

Hasil Uji Analisis Regresi Linear Berganda

\begin{tabular}{|c|c|c|c|c|c|c|}
\hline \multicolumn{7}{|c|}{ Coefficients $^{\mathrm{a}}$} \\
\hline \multirow{2}{*}{\multicolumn{2}{|c|}{ Model }} & $\begin{array}{r}\text { Unstand } \\
\text { Coeffi }\end{array}$ & dized & $\begin{array}{l}\text { Standardized } \\
\text { Coefficients }\end{array}$ & \multirow[b]{2}{*}{$\mathbf{t}$} & \multirow[b]{2}{*}{ Sig. } \\
\hline & & B & $\begin{array}{l}\text { Std. } \\
\text { Error }\end{array}$ & Beta & & \\
\hline 1 & (Constant) & $-1,416$ & 1,486 & &,- 953 &, 348 \\
\hline & Net Profit Margin & 017 & ,029 & , 109 &, 575 &, 569 \\
\hline & Total Asset Turnover & $-1,018$ & 417 &,- 303 & $-2,440$ &, 021 \\
\hline & Equity Multiplier &, 521 & ,274 & ,285 & 1,897 & 067 \\
\hline & $\begin{array}{l}\text { Return On Asset-Du } \\
\text { Pont System }\end{array}$ & ,078 &, 023 & ,738 & 3,376 & 002 \\
\hline
\end{tabular}

a. Dependent Variable: Return Saham

\section{Sumber: Data diolah SPSS}

Berdasarkan tabel diatas dapat diketahui persamaan regresi liniear berganda yaitu:

$\mathrm{Y}=-1,416$ + 0,017"X" _"1" - 1,018"X" _"2" + 0,521"X" _"3" + 0,078"X" -"4"

Berdasarkan persamaan diatas dapat dijelaskan bahwa nilai konstanta sebesar - 1,416 menyatakan bahwa nilai Net Profit Margin, Total Asset Turnover, Equity Multiplier dan Return on Equity-Dupont sama dengan nol maka return menurun -1,416. Jika variabel Net Profit Margin meningkat 1, maka akan menurunkan return sebesar 0,017, jika Total Asset Turnover menurun 1, maka akan menurunkan return sebesar - 1,018, jika Equity Multiplier meningkat 1 , maka akan menurunkan return sebesar 0,521 dan jika 
Return on Equity-DuPont System meningkat 1, maka akan menurunkan return sebesar 0,078 dengan asumsi nilai koefesien regresi variabel konstan.

\section{h.Uji t}

Berdasarkan tabel 7 hasil dari uji t dengan ketentuan yang digunakan adalah pengujian taraf signifikan $\alpha=0,05$, dengan $\mathrm{df}=\mathrm{n}-\mathrm{k}-1$, dimana $\mathrm{df}=36$ 4-1 = 31 sampel dalam penelitian setelah jumlah keselurhan 36 dikurangi menggunakan rumus $\mathrm{df}=\mathrm{n}-\mathrm{k}-1$, diperoleh "t" _"tabel" 1,695.

Uji ini dilakukan dengan membandingkan "t" _"hitung" dengan " $t$ " _"tabel" sesuai dengan kriteria sebagai berikut:

1. Apabila "t" _"hitung" < "t" _"tabel" maka, "H" _"o" diterima "H" _"a" ditolak;

2. Apabila "t" _"hitung" > "t" _"tabel" maka, "H" _"a" diterima "H" _"o" ditolak.

Tabel 7 menunjukan nilai "t" _"hitung" dari variabel Net Profit Margin 『"(X" \_"1" ) sebesar 0,575 < "t" _"tabel" 1,695 dapat disimpulkan 『"Ho" 】_"1" diterima 『"Ha" \_"1" ditolak. Maka dapat disimpulkan, Net Profit Margin tidak berpengaruh terhadap return saham dengan nilai signifikansi 0,569>0,05 menunjukan tidak berpengaruh secara signifikan. Maka dapat disimpulkan, Net Profit Margin tidak berpengaruh signifikan terhadap return saham pada Perusahaan Baru Bara periode 2014-2019 yang terdaftar di Indonesia Stock Exchange (IDX).

Pada variabel Total Asset Turnover 『"(X" \_"2") menunjukan " $t$ " _"hitung" sebesar -2,440 < "t" _"tabel" 1,695 maka dapat disimpulkan, 『"Ho" 』_"2" diterima 『"Ha" 』_"2" ditolak. Maka dapat disimpulkan, Total Asset Turnover tidak berpengaruh terhadap return saham dengan signifikansi 0,21 < 0,05 menunjukan tidak berpengaruh signifikan terhadap return saham. Maka dapat disimpulkan, Total Asset Turnover tidak berpengaruh terhadap return saham Perusahaan Batu Bara periode 2014-2019 yang terdaftar di Indonesia Stock Exchange (IDX).

Pada variabel Equity Multiplier 『"(X" 『 _ 3") menunjukan nilai "t" _"hitung" sebesar 1,897 > "t" _"tabel" 1,695 dapat disimpulkan 『"Ha" \_"3" diterima 『"Ho" \_"3" ditolak. Maka dapat disimpulkan, Equity Multiplier berpengaruh terhadap return saham dengan nilai signifikansi 0,067>0,05 menunjukan berpengaruh signifikan terhadap return saham. Maka dapat disimpulkan Equity Multiplier berpengaruh signifikan terhadap return saham Perusahaan Batu Bara periode 2014-2019 yang terdaftar di Indonesia Stock Exchange (IDX).

Pada variabel Return On Equity-DuPont System 『"(X" 』_"4") menunjukan nilai "t" _"hitung" 3,376 > "t" _"tabel" 1,695 dapat disimpulkan 『"Ha" \_"4" diterima 『"Ho" \_"4" ditolak. Maka dapat disimpulkan, 
Return on Equity-DuPont System berpengaruh terhadap return saham dengan nilai signifikansi 0,002 $<0,05$ menunjukan berpengaruh signifikan terhadap return saham. Maka dapat disimpulkan Return on Equity-DuPont System berpengaruh signifikan terhadap return saham pada Perusahaan Batu Bara periode 2014-2019 yang terdaftar di Indonesia Stock Exchange (IDX).

\section{i. Koefesien Determinasi}

\section{Tabel 9}

Hasil Uji Koefesien Determinasi

Model Summary

\begin{tabular}{|c|c|c|c|c|}
\hline Model & $\mathrm{R}$ & R Square & $\begin{array}{l}\text { Adjusted R } \\
\text { Square }\end{array}$ & $\begin{array}{l}\text { Std. Error of } \\
\text { the Estimate }\end{array}$ \\
\hline 1 & $733^{\mathrm{a}}$ & ,537 & ,477 & 7,41547 \\
\hline \multicolumn{5}{|c|}{$\begin{array}{l}\text { a. Predictors: (Constant), Return On Asset-Du Pont } \\
\text { System, Total Asset Turnover, Equity Multiplier, Net Profit } \\
\text { Margin }\end{array}$} \\
\hline
\end{tabular}

\section{Sumber: Data diolah SPSS}

Berdasarkan tabel 9dapat diketahui nilai koefesien determinasi $(\mathrm{Kd})$ sebesar 0,733 atau $53,7 \%$, ini sama dengan hasil menggunakan rumus $\mathrm{Kd}=R^{2}$ $\times 100 \%\left(0,733^{2} \times 100 \%\right)=53,7 \%$. Dapat disimpulkan bahwa Net Profit Margin (NPM), Total Asset Turnover (TATO), Equity Multiplier (EM), dan Return On Equity-DuPont System (ROE-DP) berpengaruh sebesar 53,7\% pada Perusahaan Batu Bara periode 2014-2019 yang terdaftar di Indonesia Stock Exchange (IDX) dan sisanya sebesar 46,3\% dipengaruhi oleh faktor lain yang tidak diteliti dalam penelitian ini.

\section{B. Pembahasan}

1. Pengaruh Net Profit Margin (NPM) Terhadap Return Saham Perusahaan Batu Bara Periode 2014-2019 yang Terdaftar di Indonesia Stock Exchange (IDX)

Tabel 1 menunjukan nilai thitung dari variabel Net Profit Margin $\left(\mathrm{X}_{1}\right)$ sebesar 0,575 < $\mathrm{t}_{\text {tabel }} 1,695$ dapat disimpulkan $\mathrm{Ho}_{1}$ diterima $\mathrm{Ha}_{1}$ ditolak. Maka dapat disimpulkan, Net Profit Margin tidak berpengaruh signifikan terhadap return saham pada Perusahaan Baru Bara periode 2014-2019 yang terdaftar di Indonesia Stock Exchange (IDX). Hal ini sama dengan penelitian yang dilakukan (Hakim, 2017) dengan judul "Pengaruh Price Earning Ratio, Earning Per Share, Return On Equity, Debt to Equity Ratio dan Net Profit Margin Terhadap Return Saham (Pada Sektor Property and Real Estate Yang Terdaftar Di Bursa Efek Indonesia Periode 2013-2017)" yang menunjukan hasil Net Profit Margin tidak berpengaruh signifikan terhadap return saham. Hasil penelitian ini dapat disimpulkan, apabila nilai Net Profit Margin meningkat maka perusahaan dalam keadaan kinerja yang baik dalam menghasilkan laba bersih melalui penjualan. Tidak berpengaruhnya nilai $\mathrm{Net}$ 
Profit Margin pada perusahaan batu bara periode 2014-2019 disebabkan karena lebih tingginya nilai operating market dibanding penjualan bersih yang dihasilkan perusahaan.

2. Pengaruh Total Asset Turnover (TATO) Terhadap Return Saham Perusahaan Batu Bara periode 2014-2019 yang terdaftar di Indonesia Stock Exchange

Pada variabel Total Asset Turnover $\left(\mathrm{X}_{2}\right)$ menunjukan thitung sebesar 2,440 < $\mathrm{t}_{\text {tabel }} 1,695$ maka dapat disimpulkan, $\mathrm{Ho}_{2}$ diterima $\mathrm{Ha}_{2}$ ditolak. Maka dapat disimpulkan, Total Asset Turnover tidak berpengaruh terhadap return saham Perusahaan Batu Bara periode 2014-2019 yang terdaftar di Indonesia Stock Exchange (IDX). Hal ini sama dengan penelitian yang dilakukan (Puspitasari, Herawati, \& Sulindawati, 2017) dengan judul "Pengaruh Ukuran Perusahaan, Total Asset Turnover, Return On Asset, Debt Equity Ratio, dan Earning Pershare Terhadap Return Saham Syariah Pada Perusahaan yang Terdaftar di Indonesia Sharia Stock Index (ISSI) Periode 2012-2015" yang menunjukan hasil penelitian Total Asset Turnover tidak berpengaruh secara signifikan terhadap return saham. Dari hasil penelitian tersebut maka dapat disimpulkan, jika nilai Total Asset Turnover naik maka kinerja perusahaan dalam efektivitas mencapai penjualannya baik. Tidak berpengaruhnya nilai Total Asset Turnover pada perusahaan batu bara periode 2014-2019 disebabkan karna kurangnya efisiensi perusahaan dalam memutarkan asetnya untuk mencapai penjualan. Hal ini menunjukan Hal ini menunjukan kurangnya penjualan yang dihasilkan perusahaan batu bara melalui aset yang dimilikinya.

3. Pengaruh Equity Multiplier Terhadap Return Saham Perusahaan Batu Bara Periode 2014-2019 di Indonesia Stock Exchange (IDX)

Pada variabel Equity Multiplier $\left(\mathrm{X}_{\mathrm{q}}\right)$ menunjukan nilai thitung sebesar $1,897>t_{\text {tabel }}$ 1,695 dapat disimpulkan $\mathrm{Ha}_{3}$ diterima $\mathrm{Ho}_{3}$ ditolak. Maka dapat disimpulkan Equity Multiplier berpengaruh signifikan terhadap return saham Perusahaan Batu Bara periode 2014-2019 yang terdaftar di Indonesia Stock Exchange (IDX). Hal ini sama dengan teori yang dikemukakan (Kasmir, 2017), "Equity multiplier merupakan alat untuk menggambarkan kemampuan manajemen dalam mengelola asetnya karena adanya dana yang dikeluarkan akibat dari penggunaan aset tersebut". Dari penjelasan tersebut dapat disimpulkan, apabila nilai Equity Multiplier berpengaruh terhadap kinerja perusahaan dalam mengelola aset dan jumlah hutang yang ada. Apabila nilai Equity Multiplier yang tinggi menandakan komposisi hutang lebih tinggi dibandingkan aset yang dimiliki perusahaan, begitu pula sebaliknya. Hal ini berpengaruh terhadap return saham yang akan diterima investor.

4. Pengaruh Return on Equity-DuPont System Terhadap Return Saham Perusahaan Batu Bara Periode 2014-2019 di Indonesia Stock Exchange (IDX) 
Pada variabel Return on Equity-DuPont System $\left(\mathrm{x}_{4}\right)$ menunjukan nilai $\mathrm{t}_{\text {hitung }} 3,376>\mathrm{t}_{\text {tabel }}$ 1,695 dapat disimpulkan $\mathrm{Ha}_{4}$ diterima $\mathrm{Ho}_{4}$ ditolak. Maka dapat disimpulkan Return on Equity-DuPont System berpengaruh signifikan terhadap return saham pada Perusahaan Batu Bara periode 2014-2019 yang terdaftar di Indonesia Stock Exchange (IDX). Maka dapat disimpulkan Return on Equity-DuPont System berpengaruh signifikan terhadap return saham pada Perusahaan Batu Bara periode 2014-2019 yang terdaftar di Indonesia Stock Exchange (IDX). Hal ini sama dengan teori (Sudana, 2011), "DuPont merupakan teknik analisis khusus menggambarkan bagaimana profit margin, perputaran aktiva, dan utang dikombinasikan untuk mementukan return on equity (ROE)". Dari penjelasan tersebut dapat disimpulkan, Return On EquityDuPont merupakan teknik analisis khusus dalam menentukan return on equity atau dalam kata lain Return On Equity-DuPont merupakan analisis perhitungan yang lebih menyeluruh mengenai faktor-faktor yang mempengaruhi ROE. ROE merupakan kelompok rasio profitabilitas yang digunakan untuk menggambarkan bagaimana perusahaan dalam menghasilkan laba. Semakin tinggi laba yang dihasilkan perusahaan maka akan berpengaruh terhadap return yang akan diterima, artinya tingginya nilai ROE yang dihasilkan perusahaan maka semakin tinggi pula return yang akan diterima investor.

\section{Kesimpulan}

Pada penelitian yang telah dilakukan, maka dapat disimpulkan bahwa ada beberapa hasil: Pertama, Net Profit Margin tidak berpengaruh secara parsial terhadap return saham; Kedua, Total Asset Trunover tidak berpengaruh secara parsial terhadap return saham; Ketiga, Equity Multiplier bepengaruh secara parsial terhadap return saham; dan Keempat, Return On Equity-DuPont System berpengaruh secara parsial terhadap return saham. 


\section{BIBLIOGRAFI}

Agung, Sultan, Hutasoit, Yuni Rezki, Siahaan, Yansen, Putri, Debi Eka, \& Grace, Ernest. (2019). Financial : Jurnal Akuntansi Analisis Du Pont System Dalam Mengukur Kinerja Keuangan Perusahaan Pada Pt Fast Food Indonesia, Tbk Yang Terdaftar Di Bursa Efek Indonesia Du Pont Analysis System For Measuring The Financial Performance Company At Pt Fast Foo. 5, 4049.Google Scholar

Damayanti, Lusi, Yudhawati, Diah, \& Prasetyowati, Riris Aishah. (2017). Analisis Du Pont Untuk Mengukur Kinerja Keuangan Perusahaan. Jurnal Managemen. Google Scholar

Ghozali, Imam. (2018). Aplikasi Analisis Multivariete Dengan Program IBM SPSS 23. Semarang: Universitas Diponogoro.Google Scholar

Hakim, Mohamad Zulman. Abbas Dirvi. (2017). Pengaruh Price Earning Ratio, Earning Per Share, Return On Equity, Debt To Equity Ratio Dan Net Profit Margin Terhadap Return Saham (Pada Sektor Property And Real Estate Yang Terdaftar Di Bursa Efek Indonesia Periode 2013-2017). Jurnal Akuntansi 11(1), 92-105.Google Scholar

Halim, Abdul. (2019). Analisis Investasi dan Aplikasinya (kedua). Jakarta: Salemba Empat.

Harahap, Sofyan. (2017). Analisis Kritis atas Laporan Keuangan. Jakarta: PT RajaGrafindo Persada.Google Scholar

Hery. (2016). Analisa laporan Keuangan. Jakarta: PT Gramedia Widiasarana Indonesia.

Irham, Fahmi. (2012). Pengantar Pasar Modal. Bandung: Alfabeta.Google Scholar

Izuddin, Moch. (2018). Analisis Pengaruh Faktor Fundamental Terhadap. 3, 112.Google Scholar

Kasmir. (2017). Analisis Laporan Keuangan. Jakarta: PT RajaGrafindo Persada.Google Scholar

Kasmir. (2019). Analisis Laporan Keuangan. Jakarta: PT RajaGrafindo Persada.

Munawir. (2019). Analisa Laporan Keuangan (Keempat). Yogyakarta: Liberty.

Puspitasari, Putrilia Dwi, Herawati, Nyoman Trisna, \& Sulindawati, Ni Luh Gede Erni. (2017). Pengaruh Ukuran Perusahaan, Total Asset Turnover, Return On Asset, Current Ratio, Debt To Equity Ratio, dan Earning Per Share Terhadap Return Saham Syariah Pada Perusahaan Perdagangan, Jasa, dan Investasi yang Terdaftar di Indonesia Sharia Stock Index (IS. JIMAT (Jurnal Ilmiah 
Pengaruh Return on Equity Dupont System terhadap Return Saham pada Perusahaan Batu Bara

Mahasiswa Akuntansi S1), 7(1), 1-13.Google Scholar

Sudana, I. Made. (2011). Manajemen Keuangan Perusahaan Teori dan Praktik. Jakarta: Erlangga. Google Scholar

Sunardi, Nardi. (2019). Kinerja Perusahan Pendekatan Du Pont System Terhadap Harga Dan Return Saham (Perusahaan yang tergabung dalam Industri Real Estate dan Properti yang terdaftar di Bursa Efek Indonesia Tahun 2011- 2017). Jimf (Jurnal Ilmiah Manajemen Forkamma), 1(3), 15-32. Google Scholar

Suteja, Jaja. Gunardi, Ardi. (2016). Manajemen Investasi Dan Protofolio. Bandung: PT Refika Aditama.Google Scholar

Zalmi, Zubir. (2013). Manajemen Portofolio Penerapannya dalam Investasi Saham. Jakarta: Salemba Empat.Google Scholar

\section{Copyright holder:}

Adriana Rahmawati, Evi Martaseli (2021)

\section{First publication right:}

Syntax Idea

This article is licensed under:

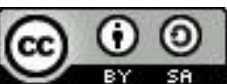

